
ISSN : 2615-1995, E-ISSN : 2615-0654

J. Madani., Vol. 2, No. 1, Maret 2019 (87 - 100)

C2018 Lembaga Kajian Demokrasi

MADANI

dan Pemberdayaan Masyarakat (LKD-PM)

\title{
PENGARUH BUDAYA ORGANISASI DAN MOTIVASI KERJA KARYAWAN PT BANK X TERHADAP KEPUASAN KERJA
}

\author{
Vivi Iswanti Nursyirwan \\ Fakultas Ekonomi, Universitas Pamulang \\ vivie.iswanti26@gmail.com
}

\begin{abstract}
Abstrak
Tujuan dari penelitian ini adalah untuk menganalisis pengaruh hubungan budaya organisasi dan motivasi kerja terhadap variabel kepuasan kerja karyawan PT Bank X. Desain penelitian ini adalah penelitian deskriptif yang menjelaskan informasi dan karakteristik populasi atau fenomena yang sedang dipelajari. Uraian yang digunakan adalah untuk perhitungan statistik. Sedangkan penelitian survei dilakukan untuk mengukur variabel melalui penyebaran kuesioner dengan 31 pernyataan yang menggunakan lima poin skala Likert. Metode yang digunakan untuk mengevaluasi hasil survei beberapa penelitian dengan regresi. Data primer yang dikumpulkan dari responden PT Bank X. Selain itu juga menggunakan data sekunder untuk mendukung informasi. Untuk menganalisis sampel yang digunakan sebagai data primer, menggunakan purposive sample. Dengan demikian, data dianalisis dengan hasil menggunakan metode korelasi. Dari hasil penelitian ini menunjukkan bahwa ada hubungan positif dan signifikan antara budaya organisasi dan motivasi kerja terhadap kepuasan kerja karyawan PT Bank X.
\end{abstract}

Kata Kunci : Budaya Organisasi, Motivasi Kerja, Kepuasan Kerja

\begin{abstract}
The objective of this research is to analyze the relationship of organization culture and work motivation towards to employee's job satisfaction of PT Bank X. The design of research is decriptive research which describes the information and characteristics of the population or phenomenon being studied. The description used is for statistical calculations, whereas a survey investigation was conducted to measure variables with spreading of questionnaries with 31 statements using five point Likert scale. The method used to calculate the survey results is multiple regression. The reseacrh is based on primary data which are collected from the respondent of PT Bank $X$ and also using secondary data to support the information. In order to analyze the primary data, purposive sampling is used to determine the sample. Thus, data were analyzed using correlation method. The results of this research is to show that there is a positive and significant relationship between organization culture and work motivation towards to employee's job satisfaction of PT Bank X.
\end{abstract}

Keywords : Organization Culture, Work Motivation, and Job Satisfaction

\section{PENDAHULUAN \\ Latar Belakang}

Manajemen Sumber Daya Manusia memegang peranan yang sangat penting dalam aktifitas perusahaan. Potensi Sumber Daya Manusia (SDM) yang ada dalam perusahaan harus dapat dimanfaatkan dengan sebaik-baiknya, sehingga mampu memberikan hasil yang maksimal. Perusahaan dan pegawai merupakan dua hal yang saling membutuhkan. Keduanya mem- bentuk hubungan layaknya simbiosis mutualisme. Jika pegawai berhasil membawa kemajuan bagi perusahaan, keuntungan yang diperoleh akan dipetik oleh kedua belah pihak. Tidak hanya bagi pegawai itu sendiri, melainkan juga bagi perusahaan. Bagi pegawai, keberhasilan merupakan aktualisasi potensi diri sekaligus peluang untuk memenuhi kebutuhan hidupnya. Sedangkan bagi perusahaan, keberhasilan pegawai merupakan sarana pertumbuhan dan 
perkembangan perusahaan serta citra positif perusahaan di mata masyarakat luas. Keberhasilan perusahaan tidak hanya dapat di capai dengan menerapkan strategi bisnis tetapi harus didukung oleh sumber daya manusia yang dimiliki oleh perusahaan. Jadi sumber daya manusia dianggap sebagai suatu kekuatan yang kompleks dimana kinerja karyawan memberikan dampak kepada perusahaan secara langsung. Apabila sumber daya manusia di dalam perusahaan dapat mencapai tujuan maka dapat dikatakan bahwa perusahaan tersebut memiliki daya kekuatan untuk berkompetisi dengan perusahaan pesaing. Salah satu tuntutan bagi perusahaan adalah dengan menciptakan sumber daya manusia yang dapat menghasilkan kinerja yang optimal dengan menjaga kepuasan kerja karyawannya.

Kualitas sumber daya manusia akan terpenuhi apabila kepuasan kerja sebagai unsur yang berpengaruh terhadap kinerja dapat tercipta dengan sempurna. (Koesmono, 2005). Karyawan yang memiliki rasa puas pada perusahaan akan menunjukkan loyalitasnya kepada perusahaan serta memberikan effort kerja yang lebih pada pekerjaannya yang pada akhirnya dapat mendatangkan opportunity keberhasilan perusahaan.

Salah satu upaya perusahaan dalam menciptakan kualitas SDM yang handal dan berkualitas ialah melalui strategi formulasi yakni penciptaan budaya organisasi yang dapat diimplementasikan oleh masing-masing pegawai. Budaya organisasi ialah sistem nilai yang diyakini semua anggota organisasi dan yang dipelajari, diterapkan serta dikembangkan secara berkesinambungan, berfungsi sebagai sistem perekat, dan dapat dipelajari, diterapkan serta dikembangkan secara berkesinambungan, budaya organisasi dapat dijadikan acuan berperilaku dalam organisasi untuk mencapai tujuan yang telah ditetapkan. Fungsi budaya organisasi ialah sebagai perekat sosial dalam mempersatukan anggota-anggota dalam mencapai tujuan organisasi berupa ketentuanketentuan atau nilai-nilai yang harus dikatakan dan dilakukan oleh para karyawan. Hal tersebut dapat berfungsi pula sebagai kontrol atas perilaku karyawan (Moeljono, 2005), keunggulan organisasi ditentukan oleh keberhasilan budaya organisasi yang dimilkinya.

Moeljono (2003) menyatakan bahwa budaya organisasi mendukung unggulnya kinerja korporasi, dan pada akhirnya keunggulan kompetitif korporasi, apapun indikator profesionalitasnya. Semakin efektif pelaksanaan budaya organisasi, akan semakin memengaruhi peningkatan produktifitas pelayanan terhadap pelanggannya. Implementasi budaya organisasi di Bank X tercermin dalam strategi formulasi Corporate Culture. Bank X berkomitmen mem- bangun hubungan jangka panjang yang didasari atas kepercayaan baik dengan nasabah bisnis maupun dengan nasabah perorangan. Bank X melayani seluruh nasabah dengan standar layanan international melalui penyediaan solusi keuangan yang inovatif. Salah satu upaya Bank X dalam melayani nasabah ialah dengan menciptakan layanan Contact Center yang bersumber pada penyediaan informasi oleh para customer service yang handal dan berkualitas, sehingga informasi yang dihasilkan dapat dipercaya, informatif, timely solution dan akurat. Mengingat pentingnya budaya organisasi terhadap pencapaian tujuan organisasi, serta dampaknya terhadap peningkatan produktifitas pelayanan yang dapat dirasakan langsung oleh nasabah, penulis setidaknya menemukan beberapa permasalahan mengenai penerapan budaya organisasi yang terdapat di PT. Bank X, khususnya di Layanan Contact Center, diantaranya: Customer Service dalam memberikan informasi kurang smailing voice, do dan don't yang sudah di buat oleh manajemen sebagai peraturan bagi para agent contact center tidak dijalankan dengan baik, khususnya dalam hal melayani nasabah, sebagai contoh : nasabah dibiarkan menunggu terlalu lama.

Mengingat bahwa setiap karyawan dalam perusahaan berasal dari berbagai latar belakang yang berbeda, maka sangat penting bagi perusahaan untuk melihat apa kebutuhan dan harapan karyawannya. Jika perusahaan dapat mengetahui hal-hal tersebut, maka akan lebih mudah untuk menempatkan karyawan pada posisi yang tepat, sehingga karyawan akan semakin termotivasi (Rivai dan Sagala, 2011).

Suatu perusahaan setidaknya harus mengusahakan agar karyawannya puas dalam menikmati pekerjaan sehingga mereka bisa lebih produktif dalam menyelesaikan pekerjaan yang menjadi bagian dari tanggung jawabnya. Untuk mewujudkan kepuasan kerja, karyawan harus dipelihara dan dirawat dengan baik agar mereka tetap memiliki motivasi tinggi (Darsono dan Siswandoko, 2011). Motivasi untuk bekerja ini sangat penting bagi tinggi rendahnya produktifitas perusahaan. Tanpa adanya motivasi dari para karyawan untuk bekerja sama bagi kepentingan perusahaan, maka tujuan yang telah ditetapkan tidak akan tercapai. Sebaliknya, apabila terdapat motivasi tinggi dari para karyawan, maka hal ini merupakan suatu jaminan atas keberhasilan perusahaan dalam mencapai tujuannya (Sutrisno, 2009). Meingingat pentingnya unsur motivasi kerja dalam suatu perusahaan dan efek negatifnya jika terdapat penurunan tingkat motivasi kerja karyawan, penulis setidaknya menemukan beberapa permasalahan mengenai motivasi kerja yang terdapat di PT. Bank X, di antaranya: menge- 
nai sistem jenjang karir, mengenai penilaian terhadap prestasi kerja karyawan, serta kurangnya ketepatan waktu dalam bekerja.

Masalah terakhir yang menjadi kajian dari penulis ialah mengenai kepuasan kerja karyawan. Salah satu faktor yang memengaruhi efektifitas organisasi dalam mencapai tujuan yang telah di tetapkan ialah kepuasan kerja (Suharsono, 2012).

Kepuasan kerja mencerminkan perasaan seseorang terhadap pekerjaannya. Hal ini dapat terlihat pada sikap positif karyawan terhadap pekerjaan dan segala sesuatu yang dihadapi di lingkungan kerjanya. Manajemen harus selalu memonitor kepuasan kerja, karena hal ini memengaruhi sikap absensi dan perputaran tenaga kerja (Sunyoto, 2012). Selain itu ketidakpuasan dalam bekerja akan dapat menunjukkan sikap menarik diri dari kontak dengan lingkungan sosialnya, sebagai contoh dengan mengambil sikap berhenti dari perusahaan, suka bolos dan perilaku lain yang cenderung bersifat menghindari dari aktifitas organisasi (Sutrisno, 2009). Dari indikator-indikator diatas, penulis menemukan pula bahwa masalah-masalah yang berhubungan dengan kepuasan kerja karyawan yang terdapat di PT Bank X. Masalah-masalah yang dimaksud ialah status kontrak bagi pegawai selama 2 tahun di nilai terlalu lama, masalah promosi yang membutuhkan waktu selama 5 tahun dinilai merupakan rentang waktu yang tidak sebentar, proses mutasi kerja yang sulit bagi seorang pegawai untuk berpindah ke disi lain.

\section{Teori Budaya Organisasi}

Menurut Koesmono (2005), Budaya organisasi berpengaruh terhadap Motivasi dan Kepuasan Kerja serta Kinerja karyawan. Secara individu maupun kelompok seseorang tidak akan terlepas dengan budaya organisasi dan pada umumnya mereka akan dipengaruhi oleh keanekaragaman sumber-sumber daya yang ada sebagai stimulus seseorang dalam bertindak. Seseorang akan selalu mendambakan penghargaan terhadap hasil pekerjaannya. Diperlukan penilaian kerja seobyektif mungkin karena akan memotivasi karyawan dalam melakukan kegiatannya. Motivasi seseorang akan memengaruhi perilaku dalam memenuhi kebutuhannya. Apabila dalam bekerjanya memperoleh kepuasan kerja sesuai dengan yang diinginkan maka seseorang akan merasa nyaman dan tinggi kesetiaannya pada perusahaan.

Dalam suatu organisasi, menurut Deming (2014) tujuan kepemimpinan organisasi harus meningkatkan kinerja manusia dan untuk meningkatkan kualitas, meningkatkan output dan secara bersamaan untuk membawa kebanggaan pengerjaan untuk orang, Deming (2004) meran- cang 5 (lima) proses langkah, sistem Pride yang membantu supervisor dan manajer untuk menciptakan lingkungan yang efisien, efektif dan produktif. Tanggung jawab untuk membangun budaya organisasi yang menyenangkan dan untuk kepuasan kerja karyawan perlu dianggap serius oleh pemimpin dalam organisasi mereka dengan mengikuti proses, sebagai berikut:

1. Menyediakan lingkungan kerja yang positif.

2. Reward dan pengakuan.

3. Melibatkan dan meningkatkan keterlibatan karyawan.

4. Mengembangkan ketrampilan dan potensi tenaga kerja.

5. Mengevaluasi dan mengukur kepuasan kerja.

\section{Motivasi Kerja}

Motivasi kerja menurut Mangkunegara (2011) ialah kondisi yang berpengaruh membangkitkan dan memelihara perilaku yang berhubungan dengan lingkungan kerja. Menurut Irum, Sultana, Ahmed dan Mahmood (2012) menjelaskan motivasi kerja ialah serangkaian proses psikologis yang menyebabkan inisiasi, arah, intensitas dan ketekunan perilaku. Soehartono (2004) menyatakan motivasi ialah suatu kehendak atau keinginan yang muncul dalam diri karyawan yang menimbulkan semangat atau dorongan untuk bekerja secara optimal guna mencapai tujuan. Sedangkan menurut Mangkunegara (2005) mengatakan motivasi merupakan kondisi atau sinergi yang menggerakan karyawan secara terarah atau tertuju untuk mencapai tujuan organisasi perusahaan.

Hasibuan (2003) mendefinisikan motivasi ialah suatu keahlian dalam mengarahkan pegawai dan organisasi agar mau bekerja secara berhasil, sehingga keinginan para pegawai dan tujuan organisasi sekaligus dapat tercapai. Mathis dan Jackson (2006) mengungkapkan bahwa motivasi ialah keinginan dalam diri seseorang yang menyebabkan seseorang tersebut bertindak. Menurut Saleem dan Mahmood (2010) mengemukakan bahwa efektifitas motivasi kerja sebagai akibat dari faktor internal maupun eksternal yang memaksa karyawan untuk bekerja dengan lebih giat dan penuh semangat yang hasilnya menjadi kepuasan kerja.

\section{Teori Motivasi Kerja}

Menurut Ario (2011) ada enam teknis aplikasi teori motivasi, yaitu : (1) manajemen berdasarkan sasaran. (2) Program penghargaan karyawan. (3) Program ketertiban karyawan (4). Program imbalan bervariasi. (5) Rencana pemberian imbalan berdasarkan keterampilan. (6). Manfaat yang fleksibel. Rivai (2006) menyatakan bahwa terdapat beberapa perilaku yang dapat memotivasi karyawan : (1). Cara interaksi. (2). Menjadi pen- 
dengar aktif. (3). Penyusunan tujuan yang menantang (4). Pendekatan penyelesaian masalah dan tujuan yang berfokus pada perilaku bukan pada pribadi. (5).Informasi yang menggunakan teknik penguatan. Mangkunegara (2005) mengemukakan bahwa terdapat 2 (dua) teknik memotivasi kerja pegawai, yaitu : (1). Teknik pemenuhan kebutuhan pegawai, artinya bahwa pemenuhan kebutuhan pegawai merupakan fundamen yang mendasari perilaku kerja. (2). Teknik komunikasi persuasif, merupakan salah satu teknik memotivasi kerja pegawai yang dilakukan dengan catra memengaruhi pegawai secara ekstra logis. Teknik ini dirumuskan dengan istilah "ADIDAS" yaitu Attention (perhatian), Interest (minat), Desire (hasrat), Desicion (Keputusan), Action (aksi atau tindakan), dan Satisfaction (kepuasan).

\section{Faktor-Faktor Motivasi}

Beberapa teori tentang motivasi yang menerangkan faktor-faktor motivasi dalam pengaruhnya terhadap produktifitas atau kinerja diantaranya sebagai berikut : Teori Motivasi Kebutuhan (Hierarchy of Needs) dari Abraham H. Maslow. Teori ini dikemukakan oleh Abraham $\mathrm{H}$. Maslow yang menyatakan bahwa manusia di motivasi untuk memuaskan sejumlah kebutuhan yang melekat pada diri setiap manusia yang cenderung bersifat bawaan. Kebutuhan ini terdiri dari lima jenis dan terbentuk dalam suatu hirarki dalam pemenuhannya. Kelima jenis kebutuhan tersebut dapat diuraikan sebagai berikut (Hariandja, 2002) :

1) Kebutuhan fisik yaitu kebutuhan ini berkaitan dengan kebutuhan yang harus dipenuhi untuk dapat mempertahankan diri sebagai makhluk fisik seperti kebutuhan untuk makanan, pakaian, dan perumahan.

2) Kebutuhan rasa aman yaitu berkaitan dengan kebutuhan rasa aman dari ancaman-ancaman dari luar yang mungkin terjadi seperti keamanan dari ancaman orang lain, ancaman bahwa suatu saat tidak dapat bekerja karena faktor usia, pemutusan hubungan kerja (PHK) atau faktor lainnya.

3). Kebutuhan sosial yaitu kebutuhan ini ditandai dengan keinginan seseorang menjadi bagian atau anggota kelompok tertentu, keinginan untuk menjalin hubungan dengan orang lain dan keinginan membantu orang lain.

4). Kebutuhan pengakuan yaitu kebutuhan yang berkaitan tidak hanya menjadi bagian dari orang lain (masyarakat), tetapi lebih jauh dari itu, yaitu diakui/dihormati/dihargai orang lain karena kemampuannya atau kekuatannya. Kebutuhan ini ditandai dengan penciptaan simbol-simbol seperti merk sepatu, merk jam, dan lainnya, merasa bahwa statusnya meningkat dan dirinya sendiri disegani dan dihormati orang.

5). Kebutuhan aktualisasi diri yaitu kebutuhan yang berhubungan dengan aktualisasi/ penyaluran diri dalam arti kemampuan/ minat/potensi diri dalam bentuk nyata dalam kehidupannya merupakan tingkat tertinggi dari teori Maslow, seperti ikut seminar, loka karya yang sebenarnya keikutsertaannya itu bukan didorong oleh ingin dapat pekerjaan, tetapi sesuatu yang berasal dari dorongan ingin memperlihatkan bahwa ia ingin mengembangkan kapasitas prestasinya yang optimal. Pada prinsipnya teori tingkat kebutuhan menurut Maslow, mengasumsikan bahwa seseorang akan berusaha memenuhi kebutuhan pokok atau tingkat rendah terlebih dahulu (fisiologis) sebelum berusaha memenuhi tingkat yang lebih tinggi, begitu seterusnya sampai mencapai tingkat kebutuhan yang tertinggi yaitu aktualisasi diri Teori Dua Faktor dari Frederick Herzberg. Teori yang dipelopori oleh Frederick Herzberg ini merupakan teori yang berhubungan langsung dengan kepuasan kerja. Menurut teori ini ada dua faktor yang memengaruhi kondisi pekerjaan seseorang. Kondisi pertama ialah faktor motivator atau faktor pemuas. Menurut Herzberg faktor motivator merupakan faktor pendorong seseorang untuk berprestasi yang bersumber dari dalam diri orang yang bersangkutan (intrinsik) yang mencakup (1). Kepuasan kerja itu sendiri, (2). Prestasi yang di raih, (3). Peluang untuk maju, (4). Pengakuan orang lain, (5). Kemungkinan pengembangan karir dan (6). Tanggung jawab. Faktor kedua ialah faktor pemelihara, yaitu merupakan faktor yang berkaitan dengan pemenuhan kebutuhan untuk memelihara keberadaan karyawan. Faktor ini merupakan kebutuhan yang paling mendasar bagi kehidupan para pegawai, karena faktor maintenance ini sebagai faktor yang besar ketidakpuasannya yang bila tidak dipenuhi sebagaimana mestinya. Faktor ini dikualifikasikan ke dalam faktor ekstrinsik yang meliputi, antara lain, (1). Kompensasi, (2). Kondisi kerja, (3). Rasa aman dan selamat, (4). Supervisi, (5). Hubungan antar manusia, (6). Status, (7). Kebijaksanaan perusahaan.

Dalam teori motivasi Herzberg, faktorfaktor motivator, meliputi prestasi, pengakuan, tanggung jawab, kemajuan, pekerjaan itu sendiri dan kemungkinan berkembang.

(1). Prestasi adalah kebutuhan untuk mem- 
peroleh prestasi di bidang pekerjaan yang ditangani. Seseorang yang memiliki keinginan berprestasi sebagai kebutuhan dapat mendorongnya mencapai sasaran.

(2). Pengakuan adalah kebutuhan untuk memperoleh pengakuan dari pimpinan atas hasil karya atau hasil kerja yang telah dicapai.

(3). Tanggung jawab adalah kebutuhan untuk memperoleh tanggung jawab dibidang pekerjaan yang ditangani.

(4). Kemajuan adalah kebutuhan untuk memperoleh peningkatan karir (jabatan).

(5). Pekerjaan itu sendiri adalah kebutuhan untuk dapat menangani pekerjaan secara aktif sesuai minat dan bakat.

(6). Kemungkinan berkembang adalah kebutuhan untuk memperoleh peningkatan karir.

(7). Frederick Herzberg memilah hirarki kebutuhan Maslow menjadi kebutuhan tingkat rendah (fisiologis, rasa aman, dan sosial) dan kebutuhan tingkat tinggi (penghargaan dan aktualisasi diri). Herzberg mengemukakan bahwa cara terbaik untuk memotivasi seseorang adalah dengan memenuhi kebutuhan tingkat tingginya.

\section{Kepuasan Kerja}

Kepuasan kerja ialah keadaan emosional yang menyenangkan atau tidak menyenangkan di mana para karyawan memandang pekerjaannya (Sunyoto, 2012). Menurut Saleem, dkk (2010) kepuasan kerja menjelaskan bagaimana karyawan merasa senang untuk datang bekerja dan bagaimana mereka bisa dipaksa untuk melakukan pekerjaan mereka dan termasuk hal-hal yang dapat membuat karyawan senang melakukan pekerjaannya dan bukan untuk memilih meninggalkan pekerjaannya. Menurut Sutrisno (2009), kepuasan kerja berhubungan erat dengan sikap dari karyawan terhadap pekerjaannya sendiri, situasi kerja, kerjasama antara pimpinan dengan sesama karyawan. Darmawan (2013) mengemukakan kepuasan kerja sebagai suatu tanggapan secara kognisi dan afeksi dari seorang karyawan terhadap segala hasil pekerjaan atau kondisi-kondisi lain yang berhubungan dengan pekerjaan, seperti gaji, lingkungan kerja, rekan kerja dan atasan.

Faktor-faktor yang Memengaruhi Kepuasan Kerja (Darmawan, 2013):

1. Pekerjaan itu sendiri. Isi pekerjaan itu sendiri ialah sumber utama kepuasan. Hal ini meliputi kemampuan pekerjaan, menyediakan tugas-tugas penting.

2. Pembayaran. Karyawan melihat pembayaran sebagai cerminan bagaimana organisasi melihat kontribusi karyawan terhadap organisasi.
3. Promosi. Kesempatan promosi mempunyai pengaruh luas terhadap kepuasan kerja.

4. Pengawasan. Ada dua dimensi gaya pengawasan yang memengaruhi kepuasan kerja, yaitu employee centeredness dan partisipasi. Employee centeredness yang diukur dengan tingkat ketertarikan personal kepada karyawan yang ditunjukkan dengan memeriksa hasil kerja bawahan, memberikan nasehat kepada bawahan, dan melakukan komunikasi yang baik. Partisipasi yaitu mengijinkan bawahan berpartisipasi dalam membuat keputusan yang memengaruhi pekerjaan mereka.

5. Suasana kerja. Suasana kerja seperti rekan kerja, kerjasama erat atau kondisi kerja yang mendukung seperti keadaan yang bersih, teratur dan nyaman.

\section{Kerangka Konseptual \\ Pengaruh Budaya Organisasi terhadap \\ Kepuasan Kerja Karyawan}

Dalam hal pencapaian tujuan organisasi, sebuah perusahaan berupaya untuk menciptakan lingkungan kerja yang kondusif sehingga karyawan yang bekerja didalamnya dapat bekerja secara baik dan menghasilkan produktifitas yang tinggi. Budaya organisasi dirancang oleh perusahaan agar karyawan dapat bekerja sesuai dengan keinginan organisasi. Budaya organisasi dapat didefiniskan sebagai seperangkat norma, nilai-nilai, kebijakan dan prosedur diikuti dalam suatu perusahaan yang penting untuk sukses menjalankan bisnis. Budaya organisasi dapat disebut sebagai etika tempat kerja, iklim organisasi dan lingkungan kerja. Budaya organisasi memiliki hubungan kuat dan terlihat dengan kepuasan kerja karyawan. Budaya organisasi ialah sistem nilainilai yang diyakini semua anggota organisasi dan yang dipelajari, diterapkan serta dikembangkan secara berkesinambungan, berfungsi sebagai sistem perekat, dan dapat dijadikan acuan berperilaku dalam organisasi untuk mencapai tujuan perusahaan yang telah ditetapkan. Fungsi budaya organisasi ialah sebagai perekat sosial, dalam mempersatukan anggota-anggota dalam mencapai tujuan organisasi berupa ketentuanketentuan atau nilai-nilai yang harus dikatakan dan dilakukan oleh para karyawan. Hal tersebut dapat berfungsi pula sebagai kontrol atas perilaku karyawan (Moeljono, 2005).

Koesmono (2005) budaya mempunyai kekuatan yang penuh, berpengaruh pada individu dan kinerjanya bahkan terhadap lingkungan kerja. Penelitian yang dilakukan oleh koesmono (2005) menyatakan bahwa budaya organisasi berpengaruh terhadap kepuasan kerja karyawan. Sedangkan penelitian yang dilakukan oleh Swathi (2014) juga mengemukakan bahwa budaya 
organisasi berpengaruh positif terhadap kepuasan kerja.

\section{Pengaruh Motivasi Kerja terhadap Kepuasan Kerja Karyawan}

Motivasi merupakan suatu hal yang sangat diperlukan oleh setiap manusia. Motivasi merupakan sebuah keahlian dalam mengarahkan karyawan pada tujuan organisasi agar mau bekerja sehingga keinginan para karyawan dan tujuan organisasi dapat tercapai. Rivai (2006) menunjukkan bahwa semakin kuat motivasi kerja, kinerja karyawan akan semakin tinggi. Seseorang yang melakukan suatu pekerjaan tanpa memiliki motivasi akan terasa hasil pekerjaannya itu hanya sia-sia belaka. Tetapi sebaliknya, dengan adanya motivasi dalam diri seseorang dalam melakukan suatu pekerjaan akan dapat membangkitkan prestasi kerja yang cukup tinggi sehingga bila pekerjaannya membuahkan hasil yang baik akan memberikan suatu kepuasan sendiri bagi manusia.

Di dalam suatu perusahaan pemberian motivasi akan menambah semangat dalam melakukan pekerjaan dan karyawan akan memberikan kinerja yang baik untuk perusahaan. Kinerja karyawan yang tinggi juga dapat dipengaruhi oleh kepuasan kerja karyawan, di mana karyawan yang merasakan kepuasan kerja yang tinggi akan menunjukkan kinerja yang tinggi. Apabila karyawan mengalami ketidakpastian dalam bekerja akan dapat menimbulkan perilaku agresif atau sebaliknya akan menunjukkan sikap menarik diri dari kontak dengan lingkungan sosial. Ketidakpuasan kerja pada karyawan juga dapat diungkapkan kedalam berbagai cara, misalnya : meninggalkan pekerjaan, menghindari sebagian tanggung jawab pekerjaan mereka (Sutrisno, 2009). Hal ini selaras dengan penelitian oleh Mafini (2014) menyimpulkan bahwa motivasi berpengaruh positif terhadap kepuasan kerja karyawan. Begitu pula penelitian yang dilakukan oleh Arifin (2014) yang menyatakan bahwa motivasi kerja berpengaruh positif terhadap kepuasan kerja karyawan. Atas dasar penelitian tersebut, maka dapat dilihat adanya pengaruh budaya organisasi, motivasi kerja terhadap kepuasan kerja karyawan.

Berdasarkan pendapat nersebut, maka kerangka pemikiran dari penelitian ini ialah sebagai berikut :

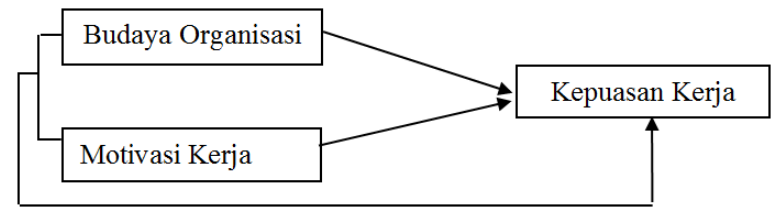

Gambar 1. Kerangka Konseptual
Kapela (2010), budaya organisasi adalah komponen kunci dalam pencapaiam misi dan strategi suatu organisasi, perbaikan efektifitas organisasi dan manajemen perubahan dimana budaya organisasi dapat berfungsi untuk memperbaiki kinerja melalui pembentukan penghambatan yang mengarahkan pencapaian tujuan. Dan juga oleh Tseng (2009) menjelaskan budaya organisasi dianggap sebagai sumber daya pengetahuan karena mengharuskan anggota untuk berkreasi, memperoleh, berbagi dan mengarahkan pengetahuan menurut suatu konteks dimana peran budaya organisasi yang berhubungan sangat kuat dengan kinerja kompetitif perusahaan yang dipengaruhi juga oleh lingkungan kerja.

Hasil penelitian terdahulu yang dilakukan oleh Jusoh, Simun dan Choy Chong(2010) menunjukkan adanya hubungan positif yang signifikan antara budaya organisasi dengan kepuasan kerja. Hasil penelitiannya menjelaskan bahwa budaya organisasi merupakan sebuah proses yang terbentuk dalam waktu yang panjang dan akan membentuk karakteristik organisasi memiliki nilai-nilai positif sehingga akan mendorong kinerja karyawan yang akan menghasilkan produktifitas dan kepuasan kerja yang tinggi bagi karyawan.

Berdasarkan paparan di atas, maka selanjutnya dirumuskan hipotesis sebagai berikut :

H1 : Terdapat pengaruh antara budaya organisasi dengan kepuasan kerja.

Motivasi kerja menurut Mangkunegara (2011) ialah kondisi yang berpengaruh membangkitkan, mengarahkan dan memelihara perilaku yang berhubungan dengan lingkungan kerja. Saleem, Mahmood dan Mahmood (2010) mengemukakan efektifitas motivasi kerja sebagai akibat dari faktor internal maupun eksternal yang memaksa karyawan untuk bekerja dengan lebih semangat untuk menjadi kepuasan kerja.

Penelitian yang dilakukan oleh Khalid, Salim, \& Loke (2011) kepada karyawan yang bekerja pada organisasi publik dan swasta di bidang industri penyediaan air minum di Malaysia. Hasil penelitiannya menyimpulkan ada pengaruh positif dan signifikan antara motivasi kerja dengan kepuasan kerja pada kedua organisasi publik dan swasta. Pernyataan tersebut sesuai dengan penelitian yang dilakukan oleh Saleem, dkk (2010) di mana disimpulkan bahwa motivasi kerja karyawan berpengaruh positif terhadap kepuasan kerja.

Maka, berdasarkan pendapat tersebut dibuatlah hipotesis sebagai berikut:

H2 : Terdapat pengaruh antara Motivasi kerja terhadap kepuasan kerja karyawan

Penelitian yang dilakukan oleh Arifin (2014) 
menyimpulkan bahwa kompetensi, motivasi dan budaya organisasi berpengaaruh positif terhadap kepuasan kerja dan kinerja karyawan. Artinya, semakin baik tingkat kompetensi, motivasi kerja dan budaya organisasi yang kuat dalam suatu organisasi akan berdampak terhadap meningkatnya kepuasan kerja dan kinerja para karyawan. Maka, berdasarkan pendapat diatas, dibuatlah hipotesisi sebagai berikut :

H3 : Terdapat pengaruh antara budaya organisasi dan motivasi kerja terhadap kepuasan kerja karyawan.

\section{Pembatasan Masalah}

Penelitian ini dilakukan untuk menguji pengaruh budaya organisasi dan motivasi kerja karyawan PT Bank X terhadap kepuasan kerja sehingga masalah penelitian dapat dirumuskan sebagai berikut :

1). Bagaimanakah pengaruh budaya organisasi terhadap kepuasan kerja karyawan?

2). Bagaimanakah pengaruh motivasi kerja terhadap kepuasan kerja karyawan?

3). Bagaimanakan budaya organisasi dan motivasi kerja secara bersama-sama berpengaruh terhadap kepuasan kerja karyawan?

Adapun untuk pembatasan masalah, penulis hanya membatasi penelitian ini di PT Bank X dan mengambil sampel dari karyawan yaitu karyawan yang bekerja di PT Bank X.

\section{METODE}

\section{Tempat dan Waktu Penelitian}

Penelitian ini mengacu kepada jurnal Swathi (2014): Impact of Organization Culture on Employee's Job Satisfaction: A Study of Public and Private Sector dan Jurnal Mafini (2014): The relationship between extrinsic motivation, job satisfaction and life satisfaction amongst employees in a public organization. Penelitian ini dilakukan untuk membuktikan hipotesis-hipotesis terkait aadanya pengaruh antara : (1). Budaya organisasi terhadap kepuasan kerja karyawan. (2).Motivasi kerja terhadap kepuasan kerja karyawan. (3). Budaya organisasi dan Motivasi kerja terhadap kepuasan kerja karyawan. Tujuan operational penelitian ini ialah untuk mengetahui hubungan dan pengaruh budaya organisasi dan motivasi kerja terhaddap kepuasan kerja karyawan di PT Bank $\mathrm{X}$, maka ditetapkan tujuan penelitian dengan menggunakan variable bebas "Independent Variable": Budaya organisasi dan Motivasi Kerja dan variabel tidak bebas : "Dependenet Variable": Kepuasan kerja karyawan.

\section{Populasi}

Penelitian ini menggunakan teknik pengambilan sampel berupa teknik purposive sam- pling. Teknik purposive sampling ialah teknik pengambilan sampel dengan pertimbanganpertimbangan tertentu berdasarkan kriteria yang dipertimbangkan (Sugiono:2005). Pertimbangan menggunakan purposive sampling dilakukan dengan tujuan untuk mendapatkan data dan informasi yang memiliki akurasi yang baik sehingga informasi yang didapatkan dapat dijadikan barometer bagi pengaruh budaya organisasi dan motivasi kerja bagi kepuasan kerja karyawan di PT Bank X.

Berikut ini beberapa kriteria yang dijadikan pedoman dalam penelitian sampel dalam penelitian :

1. Karyawan yang dijadikan sampel dalam penelitian ini ialah karyawan dengan masa kerja diatas 1 tahun.

2. Karyawan yang memiliki jenjang pendidikan minimal D3

3. Merupakan karyawan kontrak maupun karyawan tetap dio PT Bank X.

Populasi yang digunakan dalam penelitian ini ialah karyawan PT. Bank X dengan jumlah populasi sebanyak 202 orang karyawan, dari jumlah tersebut, penulis mencoba meneliti dari dua divisi yang berbeda, yakni divisi di Layanan Perbankan dan Layanan Kartu Kredit, dimana jumlah populasi untuk divisi Layanan Perbankan sebanyak 92 orang, dan divisi Layanan Kartu Kredit sebanyak 110 orang. Penentuan jumlah sampel pada penelitian ini dilakukan dengan perhitungan berdasarkan rumus slovin yang diformulasikan sebagai berikut :

$\mathrm{n}: \mathrm{N} / 1+\mathrm{Ne}^{2}$

Keterangan :

$\mathrm{n}$ : Jumlah sampel yuang dicari

$\mathrm{N}$ : Jumlah populasi

e : Perkiraan tingkat kesalahan

lain :

Hasil perhitungan populasi per divisi antara

Divisi Layanan Perbankan:

$\mathrm{n}$ : Jumlah sampel yang dicari

$\mathrm{N}$ : Jumlah populasi

e : Perkiraan tingkat kesalahan

Hasil perhitungan :

n $\quad: 92 / 1+92(0,05)^{2}=92 / 1,23=74,79$

Dengan demikian maka dari jumlah populasi untuk divisi Layanan Perbankan sebanyak 92 orang diperoleh ukuran sampel sebesar 74,79 sampel penelitian dan dibulatkan menjadi 75 orang. Kredit :

Dengan populasi untuk divisi Layanan Kartu

$\mathrm{n} \quad$ : Jumlah sampel yang dicari

$\mathrm{N}$ : Jumlah populasi

$\mathrm{e}=$ perkiraan tingkat kesalahan 
Hasil perhitungan :

n : $110 / 1+110(0.05)^{2}=110 / 1,275=86,27$

Dengan demikian maka dari jumlah populasi untuk divisi Layanan Kartu Kredit sebanyak 110 orang diperoleh ukuran sampel sebesar 86,27 sampel penelitian dan dibulatkan menjadi 86 orang.

Penelitian ini menggunakan data primer. Data dikumpulkan dengan teknik kuesioner, yaitu memberikan pernyataan tertulis kepada responden. Selanjutnya responden memberikan tanggapan atas pernyataan yang diberikan. Kuesioner penelitian bersifat tertutup dimana jawabannya sudah tersedia. Kuesioner sebagai instrumen pengumpulan data, dapat digunakan untuk mengukur fenomena sosial yang diamati pada masing-masing variabel. Untuk mendapatkan instrumen penelitian yang tepat dan terukur maka sebelumnya dilakukan uji validitas dan reliabilitas terhadap setiap item pernyataan yang ada pada setiap kuesioner. Selain data primer, penelitian ini juga menggunakan data sekunder, antara lain : berbagai jurnal, buku-buku serta sumber online.

\section{HASIL dan PEMBAHASAN \\ Hasil}

Sebelum suatu kuesioner yang merupakan instrumen dalam penelitian digunakan secara luas terlebih dahulu dilakukan uji coba untuk mengukur reliabilitas dan validitas dari alat ukur tersebut. Uji validitas dilakukan untuk mengukur sejauhmana ketepatan dan kecermatan suatu alat ukur dalam melakukan fungsi alat ukurnya. Suatu alat ukur dikatakan mempunyai validitas yang tinggi bila alat tersebut menjalankan fungsi ukurnya sesuai dengan fungsi alat ukur tersebut.

Uji reliabilitas diukur untuk melihat konsistensi dari instrumen pengukuran yang digunakan dalam penelitian. Sebuah instrumen alat ukur dikatakan reliabel bila menghasilkan skor yang konsisten pada setiap pengukuran (Uyanto,2009). Dalam uji validitas menggunakan kriteria batas nilai $r$ kritis sebesar 0,3 apabila nilai $r$ diatas 0,3 maka item dinyatakan valid. Skala pengukuran reliabilitas diukur dari batas nilai alpha cronbach dengan kriteria skala pengukuran yang reliabel memiliki nilai alpha cronbach diatas 0,6. Berikut ini ditampilkan hasil Uji Validitas dan Reliabilitas terhadap instrument penelitian yang digunakan dengan hasil sebagai berikut :

\begin{tabular}{l}
\hline \multicolumn{4}{|c|}{ Tabel 1. Hasil Uji Validitas Konstruk Budaya Organisasi } \\
\begin{tabular}{c|c|c|c|} 
No & Pernyataan & $\begin{array}{c}\text { Corrected Item- } \\
\text { Total Correlation }\end{array}$ & Keputusan \\
\hline (1) & $\begin{array}{l}\text { Perusahaan menyediakan } \\
\text { lingkungan kerja yang positif }\end{array}$ & 0,534 & Valid \\
\hline
\end{tabular}
\end{tabular}

\begin{tabular}{|c|l|c|c|}
\hline (2) & $\begin{array}{l}\text { Dalam perusahaan tempat saya } \\
\text { bekerja terdapat Reward dan } \\
\text { pengakuan }\end{array}$ & 0,402 & Valid \\
\hline (3) & $\begin{array}{l}\text { Perusahaan melibatkan dan } \\
\text { meningkatkan keterlibatan karyawan }\end{array}$ & 0,548 & Valid \\
\hline (4) & $\begin{array}{l}\text { Perusahaan mengembangkan } \\
\text { ketrampilan dan potensi tenaga } \\
\text { kerja anda }\end{array}$ & 0,406 & Valid \\
\hline (5) & $\begin{array}{l}\text { Perusahaan mengevaluasi dan } \\
\text { mengukur kepuasan }\end{array}$ & 0,209 & Valid \\
\hline \multicolumn{3}{|c|}{ Sumber: Data kuesioner diolah dengan menggunakan SPSS } \\
\hline
\end{tabular}

Pada uji reliabilitas dan validitas ini digunakan data berjumlah 131, sehingga nilai $r$ tabel adalah 0.17. Uji validitas konstruk dilakukan untuk mengukur sah atau valid tidaknya suatu kuesioner. Suatu kuesioner dikatakan valid jika pertanyaan kuesioner mampu untuk mengungkapkan sesuatu yang akan diukur oleh kuesioner tersebut. Uji signifikansi dilakukan dengan membandingkan $r_{\text {hitung }}$ dengan $r_{\text {tabel }}$ atau membandingkan nilai $\mathrm{p}$ atau sig dengan level of significance (biasanya $=0,05$ ). Jika $\mathrm{r}_{\text {hitung }}$ lebih besar dari $\mathrm{r}_{\text {tabel }}$ atau nilai $\mathrm{p}$ atau sig $<0.05$, maka pernyataan tersebut valid.

Pada tabel di atas, karena semua nilai $\mathrm{r}_{\text {hitung }}$ (Corrected Item Total Correlation) $>\mathrm{r}_{\text {tabel }}(0.17)$, maka disimpulkan bahwa indikator-indikator ini dinyatakan valid untuk digunakan sebagai alat ukur variabel.

\begin{tabular}{|c|c|c|c|}
\hline No & Pernyataan & $\begin{array}{l}\text { Corrected Item- } \\
\text { Total Correlation }\end{array}$ & Valid \\
\hline (1) & $\begin{array}{l}\text { Saya senang dengan gaji dan } \\
\text { sejumlah pekerjaan yang saya } \\
\text { lakukan }\end{array}$ & 0,374 & Valid \\
\hline (2) & $\begin{array}{l}\text { Saya senang dengan sejumlah } \\
\text { manfaat yang saya peroleh dari } \\
\text { pekerjaan saya }\end{array}$ & 0,654 & Valid \\
\hline (3) & $\begin{array}{l}\text { Saya senang dengan kebijakan } \\
\text { liburan/cuti pada pekerjaan saya }\end{array}$ & 0,452 & Valid \\
\hline (4) & $\begin{array}{l}\text { Kebijakan gaji pada pekerjaan } \\
\text { saya adil }\end{array}$ & 0,441 & Valid \\
\hline (5) & $\begin{array}{l}\text { Saya senang dengan cukupnya } \\
\text { fasilitas pada pekerjaan saya }\end{array}$ & 0,537 & Valid \\
\hline (6) & $\begin{array}{l}\text { Saya senang dengan kondisi kerja } \\
\text { pada pekerjaan saya }\end{array}$ & 0,592 & Valid \\
\hline (7) & $\begin{array}{l}\text { Saya senang dengan kualitas } \\
\text { kehidupan pekerjaan saya }\end{array}$ & 0,564 & Valid \\
\hline (8) & $\begin{array}{l}\text { Ada kerjasama tim yang baik dalam } \\
\text { organisasi }\end{array}$ & 0,433 & Valid \\
\hline (9) & $\begin{array}{l}\text { Saya selalu bisa berbicara dengan } \\
\text { rekan kerja jika Saya memiliki } \\
\text { masalah yang berhubungan dengan } \\
\text { pekerjaan }\end{array}$ & 0,514 & Valid \\
\hline (10) & $\begin{array}{l}\text { Hubungan saya dengan anggota } \\
\text { pekerjaan saya senantiasa ramah } \\
\text { dan professional }\end{array}$ & 0,512 & Valid \\
\hline (11) & $\begin{array}{l}\text { Saya telah menetapkan hubungan } \\
\text { yang saya butuhkan untuk } \\
\text { melakukan pekerjaan saya dengan } \\
\text { baik }\end{array}$ & 0,437 & Valid \\
\hline
\end{tabular}




\begin{tabular}{|c|l|c|c|}
\hline (12) & $\begin{array}{l}\text { Unit kerja lain membantu saya setiap } \\
\text { kali bantuan di perlukan }\end{array}$ & 0,455 & Valid \\
\hline (13) & $\begin{array}{l}\text { Saya senang dengan peluang untuk } \\
\text { kemajuan pada pekerjaan saya }\end{array}$ & 0,708 & Valid \\
\hline (14) & $\begin{array}{l}\text { Ada peluang yang sama bagi } \\
\text { professional untuk pengembangan } \\
\text { pekerjaan saya }\end{array}$ & 0,667 & Valid \\
\hline (15) & $\begin{array}{l}\text { Perusahaan saya akan } \\
\text { mempromosikan saya ke jenjang } \\
\text { yang lebih tinggi berdasarkan pada } \\
\text { kemampuan kerja saya }\end{array}$ & 0,733 & Valid \\
\hline (16) & $\begin{array}{l}\text { Kemungkinan untuk promosi pada } \\
\text { pekerjaan memotivasi saya untuk } \\
\text { tampil lebih baik pada pekerjaan } \\
\text { saya }\end{array}$ & 0,661 & Valid \\
\hline (17) & $\begin{array}{l}\text { Saya senang dengan kompetensi } \\
\text { pimpinan saya dalam hal membuat } \\
\text { keputusan }\end{array}$ & 0,535 & Valid \\
\hline (18) & $\begin{array}{l}\text { Saya yakin dalam hal kualitas } \\
\text { kepemimpinan atas saya }\end{array}$ & 0,578 & Valid \\
\hline (19) & $\begin{array}{l}\text { Saya senang pemimpin saya } \\
\text { memberikan umpan balik positif } \\
\text { pada pekerjaan saya }\end{array}$ & 0,612 & Valid \\
\hline (20) & $\begin{array}{l}\text { Pemimpin saya menghargai saya } \\
\text { ketika saya melakukan pekerjaan } \\
\text { dengan baik }\end{array}$ & 0,462 & Valid \\
\hline (21) & $\begin{array}{l}\text { Pemimpin saya memberi saya } \\
\text { perhatian pribadi ketika saya merasa } \\
\text { di abaikan }\end{array}$ & 0,451 & Valid \\
\hline & \multicolumn{2}{|c|}{ Sumber: Data kuesioner diolah dengan menggunakan SPSS } \\
\hline
\end{tabular}

Pada tabel di atas, karena semua nilai $r_{\text {hitung }}$ (Corrected Item Total Correlation) $>\mathrm{r}_{\text {tabel }}(0.17)$, maka disimpulkan bahwa indikator-indikator ini dinyatakan valid untuk digunakan sebagai alat ukur variabel.

\section{Tabel 3. Hasil Uji Validitas Konstruk Kepuasan Kerja}

\begin{tabular}{|c|l|c|c|}
\hline No & \multicolumn{1}{|c|}{ Pernyataan } & $\begin{array}{c}\text { Corrected Item- } \\
\text { Total Correlation }\end{array}$ & Keputusan \\
\hline (1) & $\begin{array}{l}\text { Saya merasa bangga dalam bekerja } \\
\text { di perusahaan saya }\end{array}$ & 0,533 & Valid \\
\hline (2) & Saya merasa aman dalam bekerja & 0,588 & Valid \\
\hline (3) & $\begin{array}{l}\text { Saya setuju bahwa perusahaan } \\
\text { saya mempertahankan manfaat } \\
\text { yang dapat dibandingkan dengan } \\
\text { perusahaan lain di daerah ini }\end{array}$ & 0,611 & Valid \\
\hline (4) & $\begin{array}{l}\text { Saya setuju bahwa saya menerima } \\
\text { kerja sama dengan tepat waktu dari } \\
\text { departemen lainnya }\end{array}$ & 0,536 & Valid \\
\hline (5) & $\begin{array}{l}\text { Saya setuju bahwa manajemen } \\
\text { mengakui prestasi kerja } \\
\text { karyawannya }\end{array}$ & 0,604 & Valid \\
\hline \multicolumn{3}{|c|}{ Sumber: Data kuesioner diperoleh dengan menggunakan SPSS } \\
\hline
\end{tabular}

Pada tabel di atas, karena semua nilai $\mathrm{r}_{\text {hitun }}$ (Corrected Item Total Correlation) $>\mathrm{r}_{\text {tabel }}(0.17)$ maka disimpulkan bahwa indikator-indikator ini dinyatakan Pada tabel di atas, karena semua nilai $\mathrm{r}_{\text {hitung }}$ (Corrected Item Total Correlation) > $\mathrm{r}_{\text {tabel }}(0.17)$, maka disimpulkan bahwa indikatorindikator ini dinyatakan valid untuk digunakan sebagai alat ukur variabel.

Berdasarkan hasil uji validitas diatas, maka disimpulkan bahwa semua item kuesioner yang dijadikan alat ukur untuk budaya organisasi, motivasi kerja dan kepuasan kerja dinyatakan valid dan layak digunakan sebagai alat ukur dalam penelitian.

\section{Uji Reliabilitas}

Uji Reliabilitas berkaitan dengan konsistensi, akurasi dan prediktabilitas suatu alat ukur. Reliabilitas adalah untuk mengetahui sejauhmana hasil pengukuran tetap konsisten, apabila dilakukan pengukuran dua kali atau lebih terhadap gejala yang sama dengan menggunakan alat ukur yang sama apula. Coefisient reliability diukur dengan menggunakan Cronbach's alpha bagi setiap variabel, dimana kriteria suatu instrumen penelitian dikatakan reliabel dengan menggunakan teknik ini, bila koefisien reliabilitas 0,6 (Siregar, 2013). Hasil uji reliabilitas pada penelitian ini dapat dilihat dalam tabel sebagai berikut :

\begin{tabular}{|c|c|c|c|}
\hline \multicolumn{4}{|c}{ Tabel 4. Hasil Uji Reliabilitas } \\
\hline Variabel & Items & Cronbach's Alpha & Keputusan \\
\hline $\begin{array}{c}\text { Budaya } \\
\text { Organisasi }\end{array}$ & 5 & 0,659 & Reliabel \\
\hline Motivasi Kerja & 21 & 0,908 & Reliabel \\
\hline Kepuasan Kerja & 5 & 0,791 & Reliabel \\
\hline
\end{tabular}

Berdasarkan tabel di atas, terlihat bahwa nilai Cronbach alpha seluruh variabel lebih besar dari 0,6 dengan demikian keseluruhan item dalam instrumen pengukuran dapat dinyatakan reliabel.

\section{Metode Analisis Data}

1. Untuk menganalisis budaya organisasi menggunakan nilai rata-rata yang di peroleh dari hasil olah data.

2. Untuk menganalisis motivasi kerja menggunakan nilai rata-rata yang di peroleh dari hasil olah data.

3. Untuk menganalisis kepuasan kerja menggunakan nilai rata-rata yang di peroleh dari hasil olah data.

4. Untuk menganalisis budaya organisasi terhadap kepuasan kerja menggunakan nilai rata-rata yang diperoleh dari hasil olah data.

5. Untuk menganalisis motivasi kerja terhadap kepuasan kerja menggunakan nilai rata-rata yang di peroleh dari hasil olah data.

6. Untuk menganalisis budaya organisasi dan motivasi kerja menggunakan nilai rata-rata yang di peroleh dari hasil olah data.

Data yang dikumpulkan, dianalisis dengan menggunakan analiss regresi. Analisis regresi ialah suatu analisa yang mengukur pengaruh variabel bebas dan variabel terikat (Sunyoto, 2011). Adapun analisis regresi yang digunakan dalam penelitian ini adalah analisis regresi linier berganda dan penelitian ini menggunakan bantuan program SPSS versi 22. 


\section{Pembahasan}

Untuk mengetahui persepsi responden terhadap masing-masing variabel dalam penelitian yang menggambarkan kondisi objektif dari variabel yang diamati maka dalam penelitian ini dilakukan dengan menggunakan analisis deskriptif statistik. Analisis deskriptif dalam penelitian ini dilakukan berdasarkan nilai mean dari hasil jawaban responden terhadap variabel yang dikukur melalui kuisioner.

\begin{tabular}{c|l|r|}
\hline \multicolumn{3}{c|}{ Tabel 5. Statistik Deskriptif Variabel Budaya Organisasi } \\
\hline No & \multicolumn{1}{|c|}{ Item Pernyataan } & \multicolumn{1}{c|}{ Mean } \\
\hline 1. & Menyediakan lingkungan kerja yang positif & 4.24 \\
\hline 2. & $\begin{array}{l}\text { Dalam perusahaan tempat saya bekerja terdapat Reward } \\
\text { dan pengakuan }\end{array}$ & 4.18 \\
\hline 3. & $\begin{array}{l}\text { Perusahaan melibatkan dan meningkatkan keterlibatan } \\
\text { karyawan }\end{array}$ & 3.93 \\
\hline 4. & $\begin{array}{l}\text { Perusahaan mengembangkan ketrampilan dan potensi } \\
\text { tenaga kerja anda }\end{array}$ & 3.96 \\
\hline 5. & Perusahaan mengevaluasi dan mengukur kepuasan kerja & 4.08 \\
\hline \multicolumn{2}{|c|}{ Budaya Organisasi } & 4.0809 \\
\hline \multicolumn{2}{|c|}{ Sumber : Hasil pengolahan data penelitian menggunakan SPSS Versi 22 } \\
\hline
\end{tabular}

Variabel budaya organisasi pada statistik deskriptif yang terlihat pada tabel 5 menunjukkan bahwa angka tertinggi terdapat pada item pernyataan no.1 dengan angka 4.24, dan dari itemitem pernyataan tersebut diperoleh nilai rata-rata sebesar 4.0809 maka dapat disimpulkan bahwa karyawan PT. Bank X menunjukkan sikap setuju dengan adanya pengaruh budaya organisasi.

\begin{tabular}{|c|c|c|}
\hline \multicolumn{3}{|c|}{ Tabel 6. Statistik Deskriptif Motivasi Kerja } \\
\hline No & Item Pernyataan & Mean \\
\hline 1. & $\begin{array}{l}\text { Saya senang dengan gaji dan sejumlah pekerjaan yang saya } \\
\text { lakukan }\end{array}$ & 3.74 \\
\hline 2. & $\begin{array}{l}\text { Saya senang dengan sejumlah manfaat yang saya peroleh } \\
\text { dari pekerjaan saya }\end{array}$ & 3.85 \\
\hline 3. & $\begin{array}{l}\text { Saya senang dengan kebijakan liburan/ cuti pada pekerjaan } \\
\text { saya }\end{array}$ & 3.48 \\
\hline 4. & Kebijakan gaji pada pekerjaan saya adil & 3.39 \\
\hline 5. & Saya senang dengan cukupnya fasilitas pada pekerjaan saya & 3.63 \\
\hline 6. & Saya senang dengan kondisi pekerjaan saya & 3.69 \\
\hline 7. & Saya senang dengan kualitas kehidupan pekerjaan saya & 3.55 \\
\hline 8. & Ada kerjasama tim yang baik dalam organisasi & 3.93 \\
\hline 9. & $\begin{array}{l}\text { Saya selalu bisa berbicara dengan rekan kerja jika saya } \\
\text { memiliki masalah yang berhubungan dengan pekerjaan }\end{array}$ & 4.12 \\
\hline 10. & $\begin{array}{l}\text { Hubungan saya dengan anggota pekerjaan saya senantiasa } \\
\text { ramah dan professional }\end{array}$ & 4.12 \\
\hline 11. & $\begin{array}{l}\text { Saya telah menetapkan hubungan yang saya butuhkan } \\
\text { untuk melakukan pekerjaan saya dengan baik }\end{array}$ & 3.98 \\
\hline 12. & $\begin{array}{l}\text { Unit kerja lain membantu saya setiap kali bantuan di } \\
\text { perlukan }\end{array}$ & 3.80 \\
\hline 13. & $\begin{array}{l}\text { Saya senang dengan peluang untuk kemajuan pada } \\
\text { pekerjaan saya }\end{array}$ & 3.82 \\
\hline 14. & $\begin{array}{l}\text { Ada peluang yang sama bagi professional untuk } \\
\text { pengembangan pekerjaan saya }\end{array}$ & 3.64 \\
\hline 15. & $\begin{array}{l}\text { Perusahaan saya akan mempromosikan saya ke jenjang } \\
\text { yang lebih tinggi berdasarkan pada kemampuan kerja saya }\end{array}$ & 3.66 \\
\hline
\end{tabular}

\begin{tabular}{|c|l|c|}
\hline 16. & $\begin{array}{l}\text { Kemungkinan untuk promosi pada pekerjaan memotivasi } \\
\text { saya untuk tampil lebih baik pada pekerjaan saya }\end{array}$ & 3.86 \\
\hline 17. & $\begin{array}{l}\text { Saya senang dengan kompetensi pimpinan saya dalam hal } \\
\text { membuat keputusan }\end{array}$ & 3.64 \\
\hline 18. & Saya yakin akan kualitas kepemimpinan atasan saya & 3.85 \\
\hline 19. & $\begin{array}{l}\text { Saya senang pemimpin saya memberikan umpan balik } \\
\text { positif pada pekerjaan saya }\end{array}$ & 3.98 \\
\hline 20. & $\begin{array}{l}\text { Pemimpin saya menghargai saya ketika saya melakukan } \\
\text { pekerjaan dengan baik }\end{array}$ & 4.08 \\
\hline 21. & $\begin{array}{l}\text { Pemimpin saya memberi perhatian pribadi ketika saya } \\
\text { merasa di abaikan }\end{array}$ & 3.48 \\
\hline & \multicolumn{2}{|c}{ Motivasi Kerja } \\
\hline
\end{tabular}

Variabel motivasi kerja pada statistik deskriptif yang terlihat pada tabel 6 menunjukkan untuk item per variable yang memiliki angka paling tinggi terdapat pada pernyataan no.9 dan 20 sebesar 4.12 dan dari masing-masing item pernyataan tersebut di peroleh nilai rata-rata sebesar 3.7735 maka dapat disimpulkan bahwa karyawan PT.Bank X menunjukkan sikap setuju dengan adanya pengaruh motivasi kerja.

\begin{tabular}{|c|l|r|}
\hline \multicolumn{3}{|c|}{ Tabel 7. Statistik Deskriptif Variabel Kepuasan Kerja } \\
\hline No & \multicolumn{1}{|c|}{ Item Pernyataan } & \multicolumn{1}{c|}{ Mean } \\
\hline 1. & Saya merasa bangga dalam bekerja di perusahaan saya & 3.93 \\
\hline 2. & Saya merasa aman dalam bekerja & 3.90 \\
\hline 3. & $\begin{array}{l}\text { Saya setuju bahwa perusahaan saya mempertahankan } \\
\text { manfaat yang dapat dibandingkan dengan perusahaan } \\
\text { lain didaerah ini }\end{array}$ & 3.79 \\
\hline 4. & $\begin{array}{l}\text { Saya setuju bahwa saya menerima kerja sama dengan } \\
\text { tepat waktu dari departemen lainnya }\end{array}$ & 3.62 \\
\hline 5. & $\begin{array}{l}\text { Saya setuju bahwa manajemen mengakui prestasi kerja } \\
\text { karyawannya }\end{array}$ & 3.83 \\
\hline \multicolumn{2}{|c|}{ Kepuasan Kerja } & 3.8153 \\
\hline \multicolumn{2}{|c|}{ Sumber : Hasil pengolahan data penelitian menggunakan SPSS Versi 22} \\
\hline
\end{tabular}

Berdasarkan indikator pengukuran kepuasan kerja diperoleh nilai mean sebesar 3,8153 dengan item pernyataan tertinggi diperoleh pada item pernyataan no.1., hal ini berarti jawaban responden terhadap pernyataan yang diajukan mencerminkan setuju adanya pengaruh kepuasan kerja.

Pada uji hipotesis ini, penulis menggunakan metode analisis regresi linier berganda. Analisis regresi linier berganda digunakan untuk mengetahui ada tidaknya pengaruh variabel bebas terhadap variabel terikat baik secara parsial maupun secara simultan. Untuk uji hipotesis variabel bebas terhadap variabel terikat secara parsial digunakan uji t. Hasil analisa peneliti dapat dijelaskan sebagai berikut :

\begin{tabular}{|c|c|c|c|c|c|}
\hline \multicolumn{6}{|c|}{ Model Summary ${ }^{b}$} \\
\hline Model & $\mathrm{R}$ & R Square & $\begin{array}{l}\text { Adjusted } \\
\text { R Square }\end{array}$ & $\begin{array}{l}\text { Std. Error of } \\
\text { the Estimate }\end{array}$ & $\begin{array}{l}\text { Durbin- } \\
\text { Watson }\end{array}$ \\
\hline 1 & $.746^{\mathrm{a}}$ & .557 & .550 & .44591 & 1.781 \\
\hline $\begin{array}{l}\text { a. Predict } \\
\text { b. Depen }\end{array}$ & nctan & ivasi Ke & & $\operatorname{sasi}\left(X_{1}\right)$ & \\
\hline
\end{tabular}


Nilai $R$ square $=0.557$ dari tabel di atas menunjukkan bahwa $55.7 \%$ dari varians $\mathrm{Y}$ dapat dijelaskan oleh perubahan dalam variabel $\mathrm{X}_{1}$ dan $\mathrm{X}_{2}$. Sedangkan $44.3 \%$ sisanya dijelaskan oleh faktor lain di luar model.

\begin{tabular}{|c|c|c|c|c|}
\hline \multicolumn{5}{|c|}{$\begin{array}{l}\text { Tabel 9. Hasil Uji Koefisien Determinasi } \\
\text { Divisi Layanan Perbankan }\end{array}$} \\
\hline \multicolumn{5}{|c|}{ Model Summary ${ }^{b}$} \\
\hline Model & $\mathrm{R}$ & R Square & Adjusted R Square & $\begin{array}{l}\text { Std. Error of the } \\
\text { Estimate }\end{array}$ \\
\hline 1 & $.801^{\mathrm{b}}$ & .641 & .629 & .38805 \\
\hline \multicolumn{5}{|c|}{$\begin{array}{l}\text { a. Divisi = Layanan Perbankan } \\
\text { b. Predictors: (Constant), Motivasi Kerja }\left(X_{2}\right) \text {, Budaya Organisasi }\left(X_{1}\right) \\
\text { c. Dependent Variable : Kepuasan Kerja }(Y)\end{array}$} \\
\hline
\end{tabular}

Nilai $R$ Square $=0.641$ dari tabel diatas menunjukkan bahwa pada divisi Layanan Perbankan 64.1\% dari varian Y dapat dijelaskan oleh perubahaan dalam variabel $\mathrm{X}_{1}$ dan $\mathrm{X}_{2}$. Sedangkan $35.9 \%$ sisanya dijelaskan oleh faktor lain diluar model.

\begin{tabular}{|c|c|c|c|c|}
\hline \multicolumn{5}{|c|}{$\begin{array}{c}\text { Tabel 10. Hasil Uji Koefisien Determinasi } \\
\text { Divisi Layanan Kartu Kredit }\end{array}$} \\
\hline \multicolumn{5}{|c|}{ Model Summary'ac } \\
\hline Model & $\mathrm{R}$ & $\mathrm{R}$ Square & Adjusted R Square & $\begin{array}{l}\text { Std. Error of the } \\
\text { Estimate }\end{array}$ \\
\hline 1 & $.730^{\mathrm{b}}$ & .533 & .519 & .47977 \\
\hline \multicolumn{5}{|c|}{$\begin{array}{l}\text { a. Divisi = Layanan Kartu Kredit } \\
\text { b. Predictors: (Constant), Motivasi Kerja }\left(\mathrm{X}_{2}\right) \text {, Budaya Organisasi }\left(\mathrm{X}_{1}\right) \\
\text { c. Dependent Variable: Kepuasan Kerja }(\mathrm{Y})\end{array}$} \\
\hline
\end{tabular}

Nilai $R$ square $=0.533$ dari tabel diatas menunjukkan bahwa pada divisi Layanan Kartu Kredit 53.3\% dari Varians Y dapat dijelaskan oleh perubahan dalam variabel $\mathrm{X}_{1}$ dan $\mathrm{X}_{2}$. Sedangkan $46,7 \%$ sisanya dijelaskan oleh faktor lain di luar model.

a. Uji signifikansi budaya organisasi terhadap kepuasan kerja karyawan

Bunyi hipotesis null $\left(\mathrm{H}_{0}{ }^{1}\right)$ dan hipotesis alternative $\left(\mathrm{H}_{\mathrm{a}}{ }^{1}\right)$ adalah sebagai berikut :

$\mathrm{H}_{0}{ }^{1}$ : Budaya organisasi tidak berpengaruh signifikan terhadap kepuasan kerja karyawan

$\mathrm{H}_{\mathrm{a}}{ }^{1}$ : Budaya organisasi berpengaruh signifikan terhadap kepuasan kerja karyawan

Pada perhitungan uji t jika probabilitasnya (nilai sig) $>0.05$ atau $-\mathrm{t}_{\text {tabel }}<\mathrm{t}_{\text {hitung }}<\mathrm{t}_{\text {tabel }}$ maka $\mathrm{H}_{0}$ tidak ditolak, dan jika probabilitasnya (nilai sig) $<0.05$ atau $\mathrm{t}_{\text {hitung }}<-\mathrm{t}_{\text {tabel }}$ atau $\mathrm{t}_{\text {hitung }}>\mathrm{t}_{\text {tabel }}$ maka $\mathrm{H}_{0}$ ditolak. Pada tabel diatas nilai sig variabel $\mathrm{X}_{1}=0.483>0.05$ sehingga $\mathrm{H}_{0}$ tidak ditolak, yang berarti variabel independen $\mathrm{X}_{1}$ secara parsial tidak berpengaruh signifikan terhadap variabel Y. Sedangkan koefisien beta $(\beta)$ sebesar 0,19 menunjukkan bahwa setiap ada peningkatan variabel budaya organisasi sebesar satu satuan maka meningkatkan kepuasan kerja karyawan sebesar
0,019 .

Hasil penelitian ini tidak sesuai dengan hasil penelitian yang dilakukan oleh Swathi (2014) yang meneliti pengaruh budaya organisasi terhadap kepuasan kerja karyawan. Hasil penelitiannya menyimpulkan bahwa terdapat pengaruh positif yang signifikan antara budaya organisasi dengan kepuasan kerja karyawan. Hal ini dimungkinkan karena penelitian sebelumnya dilakukan untuk Public dan Private sector.

b. Uji signifikansi motivasi kerja terhadap kepuasan kerja karyawan.

Bunyi hipotesis null $\left(\mathrm{H}_{0}^{2}\right)$ dan hipotesis alternatif $\left(\mathrm{H}_{\mathrm{a}}^{2}\right)$ adalah sebagai berikut :

$\mathrm{H}_{0}{ }^{2}$ : Motivasi kerja tidak berpengaruh signifikan terhadap kepuasan kerja karyawan.

$\mathrm{H}_{\mathrm{a}}^{2}$ : Motivasi kerja berpengaruh signifikan terhadap kepuasan kerja karyawan.

Pada tabel di atas nilai sig variabel $\mathrm{X}_{2}=0.000$ $<0.05$ sehingga $\mathrm{H}_{0}$ ditolak, yang berarti variabel independen $\mathrm{X}_{2}$ secara parsial berpengaruh positif dan signifikan terhadap variabel Y. Makin tinggi $\mathrm{X}_{2}$, makin tinggi $\mathrm{Y}$. Demikian juga sebaliknya. Koefisien beta $(\beta)$ sebesar 0,902 menunjukkan bahwa setiap ada peningkatan variabel motivasi kerja sebesar satu satuan maka akan meningkatkan kepuasan kerja sebesar 0,902 .

Hasil penelitian tersebut seduai dengan hasil penelitian yang dilakukan oleh Mafini (2014) menyimpulkan bahwa motivasi berpengaruh positif terhadap kepuasan kerja karyawan. Begitu pula penelitian yang dilakukan oleh Arifin (2014) yang menyatakan bahwa motivasi kerja berpengaruh positif terhadap kepuasan kerja karyawan. Selain itu, hasil penelitian tersebut juga sejalan dengan teori motivasi kerja yang dikemukakan oleh Saleem dan Mahmood (2010) mengemukakan bahwa efektifitas motivasi kerja sebagai motivasi kerja merupakan akibat dari faktor internal maupun eksternal yang memaksa karyawan untuk bekerja dengan lebih semangat dan penuh semangat yang hasilnya menjadi kepuasan kerja.

\begin{tabular}{|c|c|c|c|c|c|c|c|c|}
\hline \multicolumn{9}{|c|}{$\begin{array}{l}\text { Tabel 11. Hasil uji t Secara Parsial (t) } \\
\text { Divisi Layanan Perbankan }\end{array}$} \\
\hline \multicolumn{9}{|c|}{ Coefficients $^{\mathrm{a}}$} \\
\hline \multirow{2}{*}{\multicolumn{2}{|c|}{ Model }} & \multicolumn{2}{|c|}{$\begin{array}{l}\text { Unstandardized } \\
\text { Coefficients }\end{array}$} & \multirow{2}{*}{$\begin{array}{c}\begin{array}{c}\text { Standardized } \\
\text { Coefficients }\end{array} \\
\text { Beta }\end{array}$} & \multirow[b]{2}{*}{$t$} & \multirow[b]{2}{*}{ Sig. } & \multicolumn{2}{|c|}{ Collinearity Statistics } \\
\hline & & B & $\begin{array}{l}\text { Std. } \\
\text { Error }\end{array}$ & & & & Tolerance & VIF \\
\hline \multirow[t]{3}{*}{1} & (Constant) & .670 & .397 & & 1.685 & .097 & & \\
\hline & $\begin{array}{l}\text { Budaya } \\
\text { Organisasi }\left(X_{1}\right)\end{array}$ & .066 & .103 & .056 & .641 & .524 & .809 & 1.236 \\
\hline & $\begin{array}{l}\text { Motivasi } \\
\text { Keria }\left(X_{2}\right)\end{array}$ & .771 & .087 & .775 & 8.863 & .000 & .809 & 1.236 \\
\hline
\end{tabular}


a. Uji signifikan budaya organisasi terhadap kepuasan kerja karyawan di divisi Layanan Perbankan:

Bunyi hipotesis null $\left(\mathrm{H}_{0}\right)$ dan hipotesis alternatif $(\mathrm{H})$ adalah sebagai berikut :

$\mathrm{H}_{0}{ }^{1}$ : Budaya organisasi tidak berpengaruh signifikan terhadap kepuasan kerja karyawan

$\mathrm{H}_{\mathrm{a}}{ }^{1} \quad$ : Budaya organisasi berpengaruh signifikan terhadap kepuasan kerja karyawan

Hasil uji $\mathrm{t}$ pada tabel 11 adalah sebagai berikut :

Pada tabel di atas nilai sig variabel $\mathrm{X}_{1}=$ $0.524>0.05$ sehingga $H_{0}$ tidak ditolak, yang berarti variabel independen $\mathrm{X}_{1}$ secara parsial tidak berpengaruh signifikan terhadap variabel $\mathrm{Y}$. Sedangkan koefisien beta $(\beta)$ sebesar 0,066 menunjukkan bahwa setiap ada peningkatan variabel budaya organisasi sebesar satu satuan maka akan meningkatkan kepuasan kerja karyawan sebesar 0,661 .

Uji signifikansi motivasi kerja terhadap kepuasan kerja karyawan di divisi Layanan Perbankan. Bunyi hipotesis null $\left(\mathrm{H}_{0}^{2}\right)$ dan hipotesis alternatif $\left(\mathrm{H}_{\mathrm{a}}^{2}\right)$ adalah sebagai berikut :

$\mathrm{H}_{0}^{2}$ : Motivasi kerja tidak berpengaruh signifikan terhadap kepuasan kerja karyawan

$\mathrm{H}_{\mathrm{a}}{ }^{2}$ : Motivasi kerja berpengaruh signifikan terhadap kepuasan kerja karyawan.

Hasil uji t pada tabel 11 adalah sebagai berikut :

Jika probabilitasnya (nilai sig) $<0.05$ atau $\mathrm{t}_{\text {hitung }}<-\mathrm{t}_{\text {tabel }}$ atau $\mathrm{t}_{\text {hitung }}>\mathrm{t}_{\text {tabel }}$ maka $\mathrm{H}_{0}$ ditolak.

Pada tabel di atas nilai sig variabel $\mathrm{X}_{2}=0.000$ $<0.05$ sehingga $\mathrm{H}_{0}$ ditolak, yang berarti variabel independen $\mathrm{X}_{2}$ secara parsial berpengaruh positif dan signifikan terhadap variabel Y. Makin tinggi $\mathrm{X}_{2}$, makin tinggi $\mathrm{Y}$. Demikian juga sebaliknya.

Hasil penelitian tersebut sesuai dengan hasil penelitian yang dilakukan oleh Mafini (2014) yang menyimpulkan bahwa motivasi berpengaruh positif terhadap kepuasan kerja karyawan. Begitu pula penelitian yang dilakukan oleh Arifin (2014) yang menyatakan bahwa motivasi kerja berpengaruh positif terhadap kepuasan kerja karyawan.

Sedangkan koefisien beta $(\beta)$ sebesar 0,771 menunjukkan bahwa setiap ada peningatan variabel motivasi kerja sebesar satu satuan maka akan meningkatkan kepuasan kerja sebesar 0,771.

\begin{tabular}{|c|c|c|c|c|c|c|c|c|}
\hline \multicolumn{9}{|c|}{$\begin{array}{l}\text { Tabel 12. Hasil Uji Secara Parsial ( } t \text { ) } \\
\text { Divisi Layanan Kartu Kredit }\end{array}$} \\
\hline \multicolumn{9}{|c|}{ Coefficients $^{\mathrm{a}}$} \\
\hline \multirow{2}{*}{\multicolumn{2}{|c|}{ Model }} & \multicolumn{2}{|c|}{$\begin{array}{l}\text { Unstandardized } \\
\text { Coefficients }\end{array}$} & $\begin{array}{l}\text { Standardized } \\
\text { Coofficients }\end{array}$ & \multirow[b]{2}{*}{$t$} & \multirow[b]{2}{*}{ sig. } & \multicolumn{2}{|c|}{ Collinearity Statistics } \\
\hline & & B & $\begin{array}{l}\text { Std. } \\
\text { Error }\end{array}$ & Beta & & & Tolerance & VIF \\
\hline 1 & (Constant) & .802 & .584 & & -1.373 & .174 & & \\
\hline
\end{tabular}

\begin{tabular}{|l|l|r|r|r|r|r|r|r|}
\hline & $\begin{array}{l}\text { Budaya } \\
\text { Organisas }\left(X_{1}\right)\end{array}$ & .159 & .151 & .105 & 1.052 & .297 & .697 & 1.434 \\
\hline $\begin{array}{l}\text { Motivasi } \\
\text { Kerja }\left(X_{2}\right)\end{array}$ & 1.040 & .156 & .667 & 6.676 & .000 & .697 & 1.434 \\
\hline
\end{tabular}

a. Uji signifikan budaya organisasi terhadap kepuasan kerja karyawan di divisi Layanan Kartu Kredit:

Bunyi hipotesis null $\left(\mathrm{H}_{0}\right)$ dan hipotesis alternatif $\left(\mathrm{H}_{2}\right)$ adalah sebagai berikut :

$\mathrm{H}_{0}{ }^{1}$ : Budaya organisasi tidak berpengaruh signifikan terhadap kepuasan kerja karyawan

$\mathrm{H}_{\mathrm{a}}{ }^{1}$ : Budaya organisasi berpengaruh signifikan terhadap kepuasan kerja karyawan

Hasil uji $t$ pada tabel 12 adalah sebaagai berikut :

Pada tabel di atas nilai sig variabel $\mathrm{X} 1=$ $0.297>0.05$ sehingga $H_{0}$ tidak ditolak, yang berarti variabel independen $\mathrm{X}_{1}$ secara parsial tidak berpengaruh signifikan terhadap variabel $\mathrm{Y}$. Sedangkan koefisien beta $(\beta)$ sebesar 0,159 menunjukkan bahwa setiap ada peningkatan variabel budaya organisasi sebesar satu satuan maka akan meningkatkan kepuasan kerja karyawan 0,159. Uji signifikansi motivasi kerja terhadap kepuasan kerja karyawan di divisi layanan kartu kredit. Bunyi hipotesis null $\left(\mathrm{H}_{0}^{2}\right)$ dan hipotesis alternatif $\left(\mathrm{H}_{2}^{2}\right)$ adalah sebagai berikut :

$\mathrm{H}_{0}^{2}$ : Motivasi kerja tidak berpengaruh signifikan terhadap kepuasan kerja karyawan

$\mathrm{H}_{\mathrm{a}}^{2}$ : Motivasi kerja berpengaruh signifikan terhadap kepuasan kerja karyawan .

Hasil uji t pada tabel 12 adalah sebagai berikut :

Jika probabilitasnya (nilai sig) $<0.05$ atau $\mathrm{t}_{\text {hitung }}<-\mathrm{t}$ tabel atau $\mathrm{t}_{\text {hitung. }}>\mathrm{t}_{\text {tabel }}$ maka $\mathrm{H}_{0}$ ditolak. Pada tabel diatas nilai sig variabel $\mathrm{X}_{2}=0.0000<$ 0.05 sehingga $\mathrm{H}_{0}$ ditolak, yang berarti variabel independen $\mathrm{X}_{2}$ secara parsial berpengaruh positif dan signifikan terhadap variabel Y. Makin tinggi $\mathrm{X}_{2}$, makin tinggi $\mathrm{Y}$. Demikian juga sebaliknya. Hasil penelitian tersebut sesuai dengan hasil penelitian yang dilakukan oleh Mafini (2014) menyimpulkan bahwa motivasi berpengaruh positif terhadap kepuasan kerja karyawan. Begitu pula penelitian yang dilakukan oleh Arifin (2014) yang menyatakan bahwa motivasi kerja berpengaruh positif terhadap kepuasan kerja karyawan. Sedangkan koefisien beta $(\beta)$ sebesar 1,040 menunjukkan bahwa setiap ada peningkatan variabel motivasi kerja sebesar satu satuan maka akan meningkatkan kepuasan kerja karyawan sebesar 1,040. Persamaan garis regresi dari hasil penelitian pengaruh budaya organisasi dan motivasi kerja terhadap kepuasan kerja karyawan PT. Bank X dapat disimpukan sebagai 
berikut :

$\mathrm{Y}: 0.331+0.019 \mathrm{X}_{1}+0.902 \mathrm{X}_{2}$

Dari persamaan regresi tersebut jika budaya organisasi dan motivasi kerja naik, maka kepuasan kerja karyawan akan naik pula, begitu sebaliknya.

Keterangan :

$\mathrm{Y} \quad$ : variabel kepuasan kerja

$\mathrm{X}_{1}$ : variabel budaya organisasi

$\mathrm{X}_{2}$ : variabel motivasi kerja

Tabel 13. Hasil Uji Anova (Uji F)

\begin{tabular}{|c|c|c|c|c|c|c|}
\hline \multicolumn{7}{|c|}{ ANOVA $^{a}$} \\
\hline \multicolumn{2}{|c|}{ Model } & $\begin{array}{l}\text { Sum of } \\
\text { Squares }\end{array}$ & $d f$ & $\begin{array}{l}\text { Mean } \\
\text { Square }\end{array}$ & $\mathrm{F}$ & Sig. \\
\hline 1 & Regression & 31.959 & 2 & 15.979 & 80.366 & $.000^{b}$ \\
\hline & Residual & 25.451 & 128 & .199 & & \\
\hline & Total & 57.409 & 130 & & & \\
\hline
\end{tabular}

Uji $\mathrm{F}$ digunakan untuk mengetahui tingkat signifikan kontribusi variabel bebas terhadap variabel terikat secara simultan. Untuk uji F secara simultan dapat dilihat pada tabel 13 dengan penjelasan sebagai berikut:

Bunyi hipotesis null $\left(\mathrm{H}_{0}\right)$ dan hipotesis alternatif $\left(\mathrm{H}_{\mathrm{a}}\right)$ adalah sebagai berikut :

$\mathrm{H}_{0}$ : Budaya organisasi dan motivasi kerja secara bersama-sama tidak berpengaruh terhadap kepuasan kerja karyawan.

$\mathrm{H}_{2}$ : Budaya organisasi dan motivasi kerja secara bersama-sama berpengaruh terhadap kepuasan kerja karyawan.

Pada uji ANOVA, Jika probabilitasnya (nilai sig) $>0.05$ atau $\mathrm{F}_{\text {hitung }}<\mathrm{F}_{\text {tabel }}$ maka $\mathrm{H}_{0}$ tidak ditolak dan jika probabilitasnya (nilai sig) $<0.05$ atau $\mathrm{F}_{\text {hitung }}>\mathrm{F}_{\text {tabel }}$ maka $\mathrm{H}_{0}$ ditolak. Pada tabel di atas nilai sig $\stackrel{=}{=} 0.000<0.05$, sehingga $\mathrm{H}_{0}$ ditolak, yang berarti variabel-variabel independen secara bersama-sama berpengaruh signifikan terhadap variabel dependen.

\section{SIMPULAN}

\section{Kesimpulan}

Hasil penelitian budaya organisasi dan motivasi kerja terhadap kepuasan kerja karyawan PT Bank X adalah sebagai berikut :

1. Secara simultan, budaya organisasi dan motivasi kerja berpengaruh positif dan signifikan terhadap kepuasan kerja karyawan.

2. Secara parsial, budaya organisasi tidak berpengaruh terhadap kepuasan kerja karyawan PT Bank X baik di divisi layanan perbankan maupun divisi layanan kartu kredit.

3. Secara parsial, motivasi kerja berpengaruh terhadap kepuasan kerja karyawan PT Bank $\mathrm{X}$ baik di divisi layanan perbankan maupun di divisi layanan kartu kredit.

Berdasarkan hasil kesimpulan ini, maka penelitian ini dapat bermanfaat untuk meningkatkan kepuasan kerja karyawan PT Bank X dengan cara membangun budaya organisasi yang baik dan meningkatkan faktor motivasi kerja para karyawannya. Budaya organisasi dan motivasi kerja yang baik akan secara simultan memengaruhi kepuasan kerja para karyawan PT Bank X.

Dengan kepuasan kerja yang meningkat tentu akan memberi energi positif terhadap kinerja yang diharapkan manajemen. Diperlukan pola membangun budaya organisasi secara baik, penciptaan lingkungan kerja yang konfusif, membangun karakter kuat dari masing-masing pegawai, dalam hal pengimplementasian nilainilai budaya, sehingga nilai-nilai budaya dipegang teguh oleh seluruh stakeholder.

\section{Saran}

Penelitian ini tidak terlepas dari beberapa keterbatasan sehingga diharapkan keterbatasanketerbatasan tersebut mampu diperbaiki oleh peneliti selanjutnya yang melakukan penelitian mengeani pengaruh budaya organisasi dan motivasi kerja terhadap kepuasan kerja karyawan.

Adapun beberapa kekurangan dalam penelitian ini adalah :

1. Objek dalam penelitian ini hanya menggunakan satu perusahaan yang bergerak di bidang jasa perbankan sehingga hasilnya belum mampu untuk digeneralisasi secara luas, untuk penelitian selanjutnya diharapkan bisa melakukan penambahan objek dengan menambahkan objek berupa perusahaan lain yang bergerak di bidang yang sama sehingga hasil penelitiannya mampu digeneralisasikan lebih baik.

2. Penelitian ini hanya meneliti tentang budaya organisasi dan motivasi kerja yang memengaruhi kepuasan kerja karyawan, oleh karena itu, perlu adanya penelitian lebih lanjut terhadap faktor-faktor lain yang juga memengaruhi kepuasan kerja seperti faktor disiplin kerja, faktor kompensasi, faktor kompetensi kerja dan sebagainya.

\section{DAFTAR PUSTAKA}

A. A. Anwar Prabu Mangkunegara. 2011. Manajemen Sumber Daya Manusia. Rosada. Bandung.

A. A. Anwar Prabu Mangkunegara. 2005. Manajemen Sumber Daya Manusia Perusahaan. PT. Remaja Rosdakarya. Bandung.

Ahmad, Z dan Mahmood, N. 2010. Effects of Cooperative Learning vs Traditional Instruction on Prospective Teachers, Learning Expe- 
rience and Achievemen., Journal of Faculty of Educational Sciences. 43, (1), 154-164.

Arifin, Zainal. 2014. Penelitian Pendidikan:Metode dan Paradigma Baru. Remaja Rosdakarya. Bandung.

Ario, Dimas. 2011. Pengertian Metode Delphi. (online). Tersedia : http://dimasarioarumbinang.blogspot.com/2010/06/metodedelphi.html.

Darmawan, Didit. 2013. Prinsip-prinsip Perilaku Organisasi. Pena Semesta. Surabaya.

Darsono \& Siswandoko, Tjatjuk. 2011. Sumber Daya Manusia Abad 21. Nusantara Consulting. Jakarta.

Hariandja, Marihot Tua Efendi. 2002. Manajemen Sumber Daya Manusia: Pengadaan, Pengembangan, Pengkompensasian, dan Peningkatan Produktivitas Pegawai. Grasindo. Jakarta.

Hasibuan, M. 2003. Manajemen Sumber Daya Manusia. PT. Bumi Aksara. Jakarta.

Hasibuan, M. 2003. Organisasi dan Motivasi. PT. Bumi Aksara. Jakarta.

Husein Umar. 2008. Metode Riset Bisnis. PT. Gramedia Pustaka Utama. Jakarta.

Koesmono. 2005. Pengaruh Budaya Organisasi Terhadap Motivasi dan Kepuasan Kerja Serta Kinerja Karyawan. Jurnal Manajemen dan Kewirausahaan, Vol 7, no.2, September 2005 : 171-188.

Koesmono. 2005. Pengaruh Budaya Organisasi Terhadap Motivasi dan Kepuasan Kerja Serta Kinerja Karyawan. Jurnal Manajemen dan Kewirausahaan, vol. 7, no. 2., September 2005 : 171-188.

Koesmono H, Teman. 2005. Pengaruh Budaya Organisasi Terhadap Motivasi dan Kepuasan Kerja serta Kinerja Karyawan Pada Sub Sektor Industri Pengolahan Kayu Ekspor di Jawa Timur. Disertasi. Universitas Airlangga. Surabaya.

Mathis, L Robert. \& Jackson, H, Hohn. 2006. Human Resource Management. (Terjemahan Diana Angelica), Edisi Sepuluh. Salemba Empat. Jakarta.

Moeljono, Djokosantoso. 2005. Good Corporate Culture sebagai Inti dari Good Corporate Governance. PT. Elex Media Komputindo. Jakarta.

Moeljono, Djokosantoso. 2003. Budaya Korporat Dan Keunggulan Koperasi. Elex Media Komputindo. Jakarta.

Munandar, Ashar Sunyoto. 2006. Psikologi Industri dan Organisasi. Universitas Indonesia (UIPress). Jakarta.

Rivai, H.V., dan Sagala, E.J. 2011. Manajemen Sumber Daya Manusia untuk Perusahaan dari Teori ke Praktik. Edisi 2, Rajawali Pers. Jakarta.
Rivai, Veinthzal. \& Sagala, E.J. 2009. Manajemen Sumber Daya Manusia untuk Perusahaan. Rajagrafindo Persada. Jakarta.

Rivai, Veinthzal. \& Sagala, E.J. 2009. Manajemen Sumber Daya Manusia untuk Perusahaan. Rajagrafindo Persada. Jakarta

Robbins, Stephen P. 2003. Perilaku Organisasi. PT. Indeks Kelompok Gramedia. Jakarta.

Robbins, Stephen P. 2001. Organizational Behaviour. $9^{\text {th }}$ Ed. Upper Saddle River New Jersey 07458 : Prentice Hall International.

Soehartono, Irawan. 2004. Metode Penelititian Sosial. PT. Remaja Rosdakarya. Bandung.

Stephe, P. Robbins. 2002. Perilaku Organisasi. penerjemah Dr. Hadyana Pujaatmaka (edisi ketujuh) dan Benyamin Molan (perevisi) Edisi kedelapan. Penerbit PT. Prehallindo. Jakarta.

Sulthana, Afshan., Irum, Sobia.,Ahmed, Kamran dan Mehmood, Nasir. 2012. Impact of Training on Employee Performance. A Study of Telecommunication Sector in Pakistan. Interdiciplinary of Journal of Contemporary Research in Business, Vol. 4. No. 646-661.

Sunyoto, D. 2012 Manajemen Sumber Daya Manusia. CAPS. Yogyakarta.

Sutrisno, Edy. 2009. Manajemen Sumber Daya Manusia. Edisi Pertama, Cetakan Pertama. Penerbit Kencana. Jakarta.

Sutrisno, Edy. 2009. Manajemen Sumber Daya Manusia. Edisi Pertama, Cetakan Pertama. Penerbit Kencana. Jakarta.

Sutrisno, Edy. 2009. Manajemen Sumber Daya Manusia. Edisi Pertama, Cetakan Pertama. Penerbit Kencana. Jakarta.

Umaar, Husein. 2004. Sumber Daya Manusia Dalam Organisasi. Gramedia Pustaka Utama. Jakarta.

Impact of Organization Culture on Employee's Job Satisfaction : A Study of Public and Private Sectore : Sumedha Journal of Management, 2014.

The Relationship Between extrinsic Motivation, Job Satisfaction and Life Satisfaction Amongst Employees in Public Organization, International Journal, Mafini, 2014. 